\title{
Initiation of winter phytoplankton blooms within the Gironde plume waters in the Bay of Biscay
}

\author{
C. Labry ${ }^{1, *}$, A. Herbland ${ }^{1}$, D. Delmas ${ }^{1}$, P. Laborde ${ }^{2}$, P. Lazure ${ }^{3}$, J. M. Froidefond ${ }^{4}$, \\ A. M. Jegou ${ }^{3}$, B. Sautour ${ }^{2}$ \\ ${ }^{1}$ Centre de Recherche en Ecologie Marine et Aquaculture, CNRS-IFREMER, BP 5, 17137 L'Houmeau, France \\ ${ }^{2}$ Laboratoire d'Océanographie Biologique, Université Bordeaux 1, Avenue des Facultés, 33405 Talence, France \\ ${ }^{3}$ Institut Français de Recherche pour l'Exploitation de la Mer (IFREMER), Direction de l'Environnement Littoral, \\ Applications Opérationnelles, Centre de Brest, BP 70, 29280 Plouzané, France \\ ${ }^{4}$ Département de Géologie et d'Océanographie, Université Bordeaux 1, Avenue des Facultés, 33405 Talence, France
}

\begin{abstract}
Thermostratification and seasonal light increase are generally considered the first causes of phytoplankton spring blooms in temperate waters. The objective of this study is to confirm the existence of winter phytoplankton blooms, responsible for the early exhaustion of phosphate, within the Gironde plume waters (southeast Bay of Biscay), and to understand what may initiate them so early. Two cruises, BIOMET 2 and BIOMET 3, were carried out respectively in early (8 to 21 January) and late winter 1998 (25 February to 11 March). An increase of phytoplankton biomass (chl a) between the 2 cruises and non-conservative nutrients observed in late winter confirm an early phytoplankton growth both in the Gironde plume and adjacent oceanic waters. Among factors that possibly initiate these blooms, light availability seems to be the best candidate. First, the status of available light for phytoplankton changed dramatically between the 2 cruises when comparing the instantaneous depth-averaged irradiance $\left(E_{\mathrm{m}}\right)$ received by phytoplankton with the light saturation parameter $E_{k}$ determined from $P$ versus $E$ curves. Light was limiting for phytoplankton growth in early winter according to systematically lower values of $E_{\mathrm{m}}$ than $E_{k}$ in the daytime. However, light was not limiting during a large part of the day in late winter since $E_{\mathrm{m}}$ was above $E_{k}$ during $40 \%$ of the daylight. The estimated critical depth from the Nelson \& Smith (1991; Limnol Oceanogr 36:1650-1661) reformulation of the Sverdrup (1953; J Cons Perm Int Explor Mer 18:287-295) equation was much shallower (4 to $13 \mathrm{~m}$ ) than the mixed layer depth (15 to $50 \mathrm{~m}$ ) in early winter in the whole Gironde plume up to oceanic waters. On the contrary, it was much deeper (35 m) than the mixed layer depth $(9 \mathrm{~m})$ in late winter for the intermediate plume (salinity range 33 to 35 ) and similar for oceanic waters ( $\mathrm{S}>35.5$ ) with a bottom depth of 60 to $70 \mathrm{~m}$. Therefore, according to the Sverdrup model, available light is the triggering factor of winter phytoplankton blooms in the Gironde plume and adjacent oceanic waters. Moreover, Riley's (1957; Limnol Oceanogr 2:252-270) empirical critical irradiance of $20.9 \mathrm{~W} \mathrm{~m}^{-2}$ could be applied in these waters to predict the onset of blooms since it was reached in late winter but not in early winter. The establishment of halostratification and/or decrease of the light vertical attenuation coefficient prevail in the initiation process of winter phytoplankton blooms.
\end{abstract}

KEY WORDS: Winter blooms $\cdot$ Light availability $\cdot$ Halostratification $\cdot$ Vertical attenuation coefficient

\section{INTRODUCTION}

*Present address: Maison de la Recherche en Environnement Naturel, 32 avenue Foch, 62930 Wimereux, France.

E-mail: labry@mren2.univ-littoral.fr
The Bay of Biscay belongs to the Northeast Atlantic Shelves Province, 1 of the 56 marine provinces defined by Longhurst (1995, 1998). According to chlorophyll data from the Coastal Zone Colour Scanner (CZCS) 
sensors, Longhurst (1998) recognizes 4 ecological seasons in that province: (1) mixed conditions and light limitation in winter, (2) a nutrient-limited spring bloom, (3) stratified conditions during summer with localized zones of high chlorophyll along fronts, and (4) a second general bloom when the autumn gales break down the summer stratification. This is a shorthand version of the classical plankton calendar for the European continental shelf. In terms of primary production intensity, the main feature is the establishment of 'thermal' stratification in spring, resulting from increasing incident irradiance and heat (Varela 1996). This decreases the depth of the mixed layer, and therefore increases the effective mean light received by phytoplankton, which reach positive net photosynthesis and can then outburst (Sverdrup 1953).

Of course, many regional particularities and exceptions exist within the Bay of Biscay. For instance, physical forcing by tidal currents has a great influence northwest of the Bay of Biscay on the Armorican shelf, near Ushant Island. It creates vertical mixing all year round without any possibility of stratification (Morin et al. 1991). During summer, the wind regime in the Cantabrian Sea, along the Spanish coast, induces a coastal upwelling (Botas et al. 1990) which stimulates the phytoplankton production previously nutrient-limited due to thermal stratification (Varela 1996). As a result, the highest rates of photosynthetic carbon incorporation have been measured during the summer upwelling event rather than during the spring bloom (Fernández \& Bode 1991, Varela 1996).

A main exception to the first role of thermal stratification (Varela 1996, Longhurst 1998) in the initiation of phytoplankton blooms could be the 'haline' stratification. In the northwestern part of the Bay of Biscay, halostratification due to freshwater runoff was proved to be responsible for early phytoplankton development in the Bay of Brest (Ragueneau et al. 1996) and in the haline frontal zones of South and West Brittany (Morin et al. 1991). However, the late blooming in the central part of the Armorican continental shelf is linked to the late establishment of a thermocline (Morin et al. 1991). Freshwater extension of large French rivers on the Bay of Biscay continental shelf constitutes an important physical forcing. During some years (e.g. 1994 and 1995), the Loire and Gironde plumes were connected. The large part of the shelf is influenced by lowsalinity vertically stratified waters (Lazure \& Jegou 1998), inducing the water column stability required for the outburst of phytoplankton, before that induced by thermostratification. The physical regulation of phytoplankton blooms by river flow-induced stratification, and more generally the rule of haline stratification, has previously been shown in coastal (Erga \& Heimdal 1984, Levasseur et al. 1984, Thórdardóttir 1986, Yin et al. 1996) and estuarine waters (Cloern 1984, Ingram et al. 1985, Pennock 1985, Pennock \& Sharp 1994).

Herbland et al. (1998) have pointed out that the spring phytoplankton growth in the Gironde plume was severely phosphorus-limited. The objective of the present study is to test the hypothetical conclusions of this previous paper: 'classical' phytoplankton blooms should occur earlier in the year, because of the conjunction of favourable climatic (light, winds regime) and hydrological (Gironde runoff, stratification) conditions. They could be responsible for the early exhaustion of phosphate.

\section{MATERIALS AND METHODS}

Sampling strategy. Two cruises were carried out aboard the French RV 'Thalassa' in the Gironde plume waters during the winter of 1998: BIOMET 2 (8 to 21 January) and BIOMET 3 (25 February to 11 March). The 2 cruises consisted of a grid of stations covering the spread of the Gironde plume from estuarine to oceanic waters (Fig. 1).

In order to develop an accurate description of the plume during each cruise, the size of the grid and the number of stations were chosen according to (1) the predictions of the 3D hydrodynamical model (Lazure \& Jegou 1998), taking into account Gironde runoff values, direction, and velocity of winds and tidal currents a few days before the beginning of each

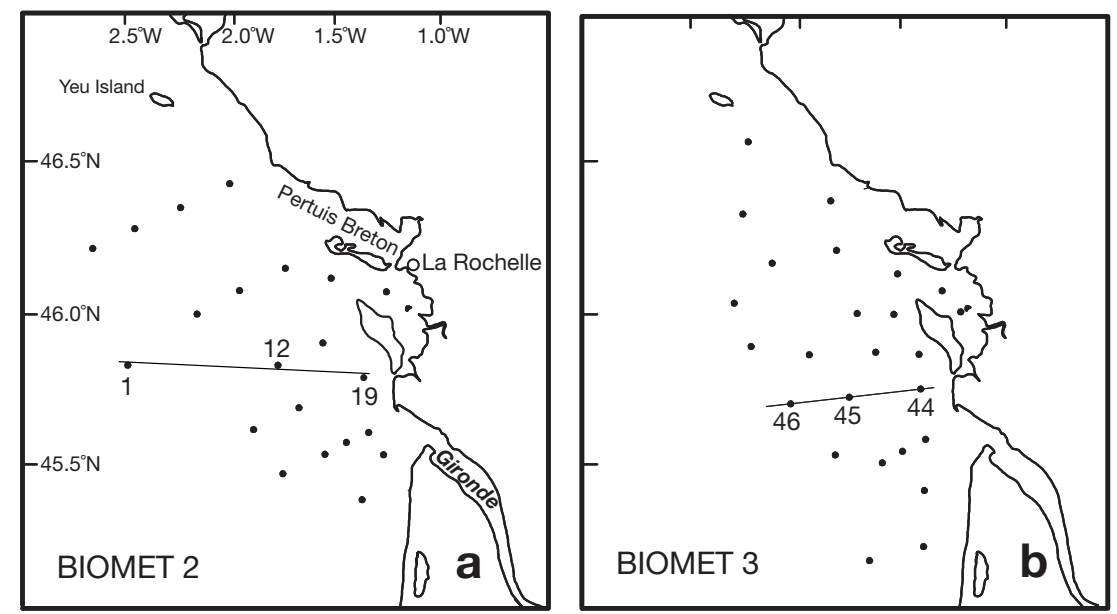

Fig. 1. Grid of stations for the cruises (a) BIOMET 2 and (b) BIOMET 3 
cruise, (2) the Sea-viewing Wide Field-of-view Sensor (SeaWiFS) imagery received on board, and (3) the continuous subsurface temperature and salinity records taken by an onboard thermo-salinograph.

Since both cruises were in winter, we use 'early winter' and 'late winter' in the following sections when we refer to the observations from BIOMET 2 and BIOMET 3 respectively.

Physical environment. Temperature and salinity profiles were measured with a CTD probe (Sea Bird, SBE9/11) coupled with a rosette system composed of Niskin bottles. The system was also equipped with light sensors (Biospherical QSP-200) to simultaneously measure the surface and depth profile of photosynthetically available radiation ( $\mathrm{PAR}_{;} 400$ to $700 \mathrm{~nm}$ ).

From temperature and salinity profiles, the density vertical distribution was determined and the depth of the mixed layer $\left(z_{\mathrm{m}}\right)$ was estimated as the depth at which the density difference $\Delta \sigma_{t}$ becomes $>0.2 \mathrm{~kg} \mathrm{~m}^{-3}$ with respect to surface density. The vertical attenuation coefficient $K$ for PAR was calculated from the relation between irradiance $\left(E_{z}\right)$, surface irradiance $\left(E_{0}\right)$ and depth $z$ using PAR data: $E_{z}=E_{0} \times \mathrm{e}^{-K z} . K$ is the slope of the linear regression between $\ln E_{z}$ and depth $z$. Depth of the euphotic layer $z_{\mathrm{e}}$ was assumed to be the depth of $1 \%$ of surface irradiance and was determined by $Z_{\mathrm{e}}=-(\ln 0.01) / K$.

From January to the end of March 1998, total surface incident irradiance (within spectral range 300 to $2500 \mathrm{~nm} \mathrm{~W} \mathrm{~m}^{-2}$ ) was continuously monitored with an Aanderaa pyranometer (model 2770) located $5 \mathrm{~km}$ north of La Rochelle (see Fig. 1a). These measurements were validated with meteorological data from Meteo France at La Rochelle. They were converted to PAR (400 to $700 \mathrm{~nm} ; \mu$ Einst $\mathrm{m}^{-2} \mathrm{~s}^{-1}$ ) using the ratio of the energy in the band 400 to $700 \mathrm{~nm}$ to total energy (0.425) according to Jitts et al. (1976), Morel \& Smith (1974) average of quanta per unit energy $\left(2.77 \times 10^{18}\right.$ quanta $\left.\mathrm{s}^{-1} \mathrm{~W}^{-1}\right)$.

Chemical and biological variables. Seawater samples for measurement of nutrients were filtered on glass fiber filters (Whatman GF/F) with a syringe filtration system. Phosphate was analysed onboard immediately after sampling on a spectrophotometer (Shimadzu UV 160) with a $10 \mathrm{~cm}$ optical path cell. Samples for nitrate, nitrite and silicate measurements were stored in polyethylene flasks, frozen $\left(-20^{\circ} \mathrm{C}\right)$ and analysed later in the laboratory on an autoanalyser apparatus (Skalar). Phosphate, nitrate, nitrite and silicate concentrations were determined according to the classical methods described by Strickland \& Parsons (1972) with the respective detection limit of $0.02,0.05,0.03$ and $0.1 \mu \mathrm{M}$ and the respective precision of $0.01,0.05$, 0.02 and $0.1 \mu \mathrm{M}$.

Suspended particulate organic matter (SPM) concentrations were obtained by filtration of seawater on preweighted $47 \mathrm{~mm}$ Whatman GF/F filters. Filters were washed rapidly with rinses of distilled water (volume $<5 \mathrm{ml}$ ), dried for $3 \mathrm{~h}$ at $50^{\circ} \mathrm{C}$ and then frozen.

Particulate organic carbon (POC) and nitrogen (PON) were measured by filtration of seawater on precombusted $\left(12 \mathrm{~h}\right.$ at $\left.400^{\circ} \mathrm{C}\right) 25 \mathrm{~mm}$ Whatman GF/F filters. The filters were then frozen. At the laboratory filters were fumed overnight with $\mathrm{HCl}$ (36\% final conc.) to remove the inorganic carbon. The amount of POC and PON was determined in a CHN analyzer (Carlo Erba 1500). For particulate organic phosphorus (POP) determination, $47 \mathrm{~mm} \mathrm{GF/F}$ filters were acid-washed $(\mathrm{HCl}$ $1 \mathrm{~N}$ ) before precombustion. After filtration, filters were frozen and analysed with the persulfate oxidation procedure (Pujo-Pay \& Raimbault 1994).

Total chlorophyll a (chl a) and phaeopigments (Phae) were determined by filtration of seawater on to $47 \mathrm{~mm}$ Whatman GF/F for the stations of the grid. Size fractionation was achieved at 5 to 8 stations. Total chl a was then measured by filtration on to $0.4 \mu \mathrm{m}$ Nuclepore polycarbonate filters, size fraction limits being respectively $3 \mu \mathrm{m}$ (Nuclepore polycarbonate filters) and $20 \mu \mathrm{m}$ (nylon sieve). Filters were frozen and analysed later by the fluorometric acidification procedure in $90 \%$ acetone extracts (Holm-Hansen et al. 1965).

Determination of phytoplankton species larger than $20 \mu \mathrm{m}$ was achieved in late winter only by filtration of seawater (1 l) on to a $20 \mu \mathrm{m}$ nylon sieve. The sieve was dipped in $80 \mathrm{ml}$ of filtered seawater, then discarded. The sample was stored in darkness after the addition of $2 \mathrm{ml}$ of Lugol's solution.

The 'light saturation parameter' $\left(E_{k}\right)$, which is the intercept between the initial slope of the $P$ versus $E$ curves and the maximum photosynthetic rate $\left(P_{\mathrm{m}}^{*}\right)$ (Talling 1957, Sakshaug et al. 1997), was measured at some stations during BIOMET 3 by light-saturation experiments. The method was a slight modification of the small volume, short-incubation time procedure by Lewis \& Smith (1983): $5 \mathrm{ml}$ of seawater homogeneously labelled with $2 \mu \mathrm{Ci}$ of ${ }^{14} \mathrm{C}$ bicarbonate $\left(\sim 1.5 \times 10^{4} \mathrm{~Bq}\right.$ $\mathrm{ml}^{-1}$ ) were introduced into scintillation vials $(20 \mathrm{ml})$. In a 'photosynthetron' 24 samples were incubated for $30 \mathrm{~min}$ with a light gradient ranging from 1 to $1600 \mu$ Einst $\mathrm{m}^{-2} \mathrm{~s}^{-1}$. Temperature was regulated and fixed for each experiment at the in situ temperature. Samples were then fixed with formaldehyde, shaken after addition of $100 \mu \mathrm{l}$ of hydrochloric acid ( $2 \mathrm{~N})$, then stored in darkness until counting at the laboratory. The photosynthetic rate $(P)$ data were normalized to chl a concentration $\left(P^{*}\right)$ and they were plotted as a function of irradiance $E$. The hyperbolic tangent equation of Jassby \& Platt (1976), $P^{*}=P_{\mathrm{m}}^{*} \times \tanh \left(\alpha \times E / P_{\mathrm{m}}^{*}\right)$, was applied to the data by least-squares fittings. $E_{k}$ estimations were calculated as values of the ratio $P_{\mathrm{m}}^{*} / \alpha$ (Sakshaug et al. 1997). 


\section{RESULTS}

\section{Hydrological characteristics}

Spatial extent of the Gironde plume

In early winter, the Gironde plume spread northward and alongshore with pronounced horizontal gradients from the coast to offshore (Fig. 2a). The isohaline 35.5, which could be considered as the limit between plume and oceanic adjacent waters, corresponded roughly to bottom depth of 50 to $60 \mathrm{~m}$ (data not shown). In late winter, horizontal salinity gradients were weak, and the Gironde plume spread offshore (60 to $70 \mathrm{~m}$ ) (Fig. 2b). A southward extension of the Loire plume waters was seen southeast of Yeu Island (shown in Fig. 1a) during BIOMET 3. As a result, Loire and Gironde waters mixed in that region.

Both in early and late winter, Gironde plume surface waters were colder than oceanic surface waters
(Fig. 2c,d) (Castaing et al. 1999). Temperatures measured during BIOMET 3 in surface plume waters (10.5 to $11.5^{\circ} \mathrm{C}$ ) were lower than those measured during BIOMET $2\left(11.5\right.$ to $\left.12^{\circ} \mathrm{C}\right)$. This was also the case for oceanic waters with respectively 12 to $12.5^{\circ} \mathrm{C}$ during BIOMET 3 and 12.5 to $13.5^{\circ} \mathrm{C}$ during BIOMET 2 .

\section{Vertical distribution}

Vertical salinity and temperature differences were very weak in early winter within the area influenced by plume waters (Fig. 3a,b), since they were generally less than 0.5 and $0.2^{\circ} \mathrm{C}$ respectively. Oceanic waters ( $\mathrm{S}>35.5$ ) were homogeneous in salinity and temperature in early winter (Fig. 3c). Storms occurred during BIOMET 2 with typical strong winds $\left(>25 \mathrm{~m} \mathrm{~s}^{-1}\right)$ which enhanced vertical mixing.

In late winter, vertical temperature differences were weak in plume waters $\left(<1^{\circ} \mathrm{C}\right.$ with colder waters in the mixed layer) (Fig. 3d,e). However, haline stratification was strong between the end of January and the beginning of March in the Gironde plume waters (salinity range $\approx 33$ to 35 ): vertical differences up to 1.5 or 2 were measured, establishing a 3 to $10 \mathrm{~m}$ low-salinity mixed surface layer (Fig. 3d,e, Table 1). Oceanic waters (with a bottom depth of 60 to $70 \mathrm{~m}$ ) were still homogeneous in salinity and temperature (Fig. 3f).

\section{Values of vertical attenuation coefficient $(K)$ and depth of euphotic layer $\left(z_{\mathrm{e}}\right)$}

Values of $K$ showed pronounced spatial variability with a negative gradient from turbid plume (salinity <33), through intermediate plume (salinity range 33 to 35 ) to oceanic waters during the 2 cruises (Table 1). For both cruises $K$ was strongly correlated to the SPM concentration (linear correlation coefficient $r$ of 0.971, Fig. 4). Values of $K$ strongly decreased between the cruises, affecting $z_{\mathrm{e}}$. In early winter, the euphotic layer was always shallower than the mixed layer. This was also the case for oceanic waters in late winter.
Fig. 2. Spatial distributions of surface salinity and temperature $\left({ }^{\circ} \mathrm{C}\right)$ in the Bay of Biscay continental shelf during BIOMET 2 and BIOMET 3 


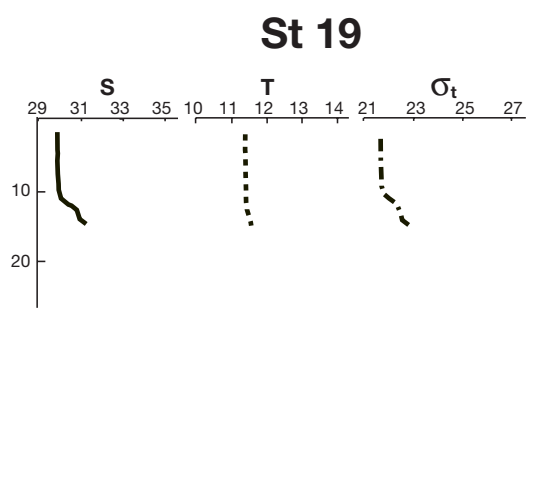

BIOMET 2 a

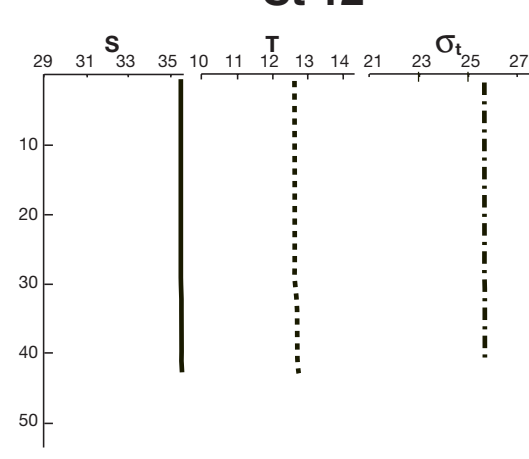

BIOMET 2 b

\section{St 1}

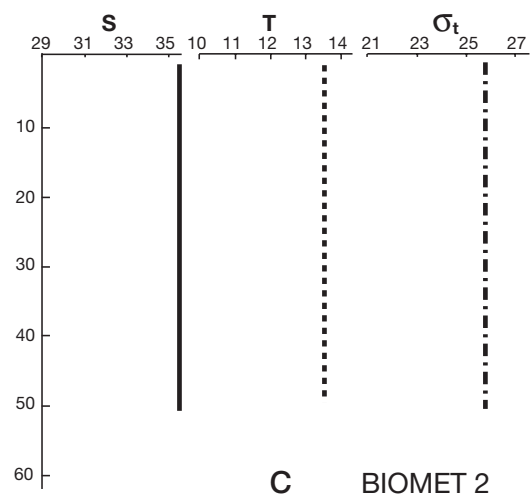

\section{St 44}

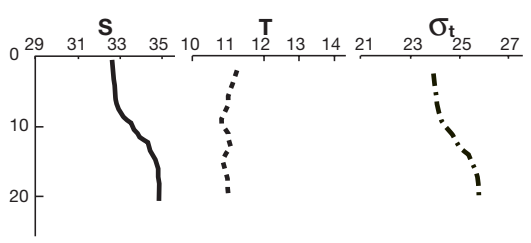

BIOMET 3

\section{d}

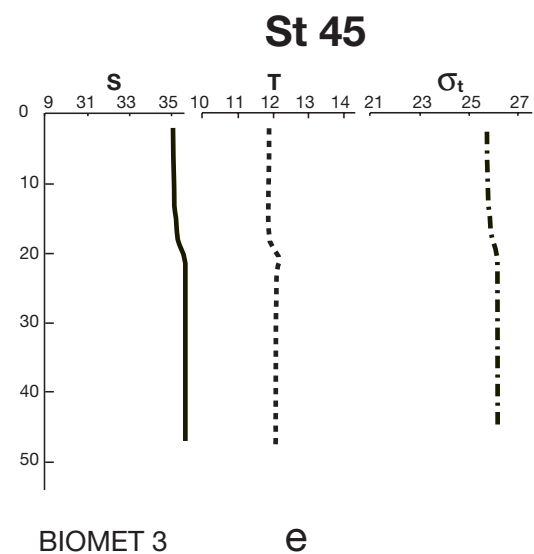

St 46

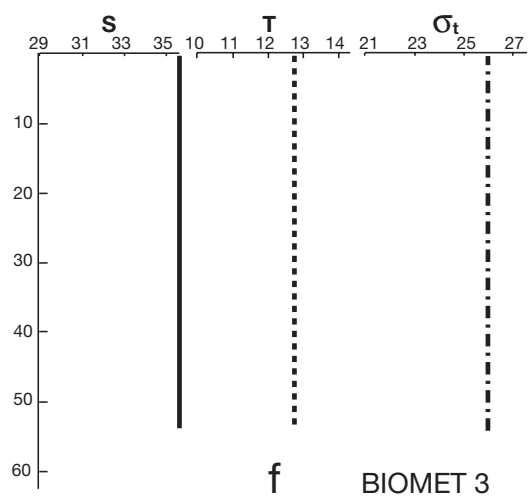

Fig. 3. Vertical distributions of salinity, temperature and density during BIOMET 2 and BIOMET 3 at 3 stations along transects shown in Fig. 1

However, the euphotic layer of the intermediate plume became deeper than the mixed layer in late winter.

\section{Nutrients}

\section{Range and spatial distributions}

In early winter, phosphate, nitrate and silicate concentration ranges from Atlantic oceanic waters to Gironde waters (salinity $=30$ ) were respectively 0.15 to $0.8,2$ to 40 and 1.5 to $25 \mu \mathrm{M}$, which reflects nutrient enrichment in the outflow of the Gironde River (Fig. 5a,c,e). During that period phosphate of the whole Gironde plume and estuarine waters was conservative in the salinity range 16 to 35 (Fig. 6a), as were nitrate and silicate (results not shown). As a consequence, isopleths of nutrients in the mixed layer closely paralleled the surface isohalines (Figs. 2a \& 5a,c,e).

In late winter, nutrients in the mixed layer had decreased. They ranged from 0 to $0.5 \mu \mathrm{M}$ for phosphate, 0 to $20 \mu \mathrm{M}$ for nitrate and 0.1 to $20 \mu \mathrm{M}$ for sili- cate (Fig. 5b,d,f). The influence of Loire plume waters was again observed southeast of Yeu Island by an increase of nitrate concentrations. Nutrients were still conservative within the salinity range 16 to 33 (Fig. 6b), but not above 33, which led to deviations between the isopleths of nutrients and salinity (Figs. $2 b \& 5 b, d, f)$. Differences were particularly important for silicate (conc. $<2 \mu \mathrm{M}$ ) and phosphate in the Gironde plume for which extremely low concentrations were recorded, frequently at the detection limit of the method $(0.02 \mu \mathrm{M})$.

\section{Vertical distributions}

In early winter, nutrients exhibited mostly homogeneous vertical distribution, and average concentrations are shown in Table 2 . The vertical distribution of nutrients changed dramatically between BIOMET 2 and BIOMET 3. A strong stratification became established in late winter with different shapes of distribution, according to the different nutrients (Table 2). Above salinity 33, phosphate was exhausted from the mixed layer, and it 
Table 1. Mean value of the vertical attenuation coefficient $K\left(\mathrm{~m}^{-1}\right)$, the depth of the euphotic layer $z_{\mathrm{e}}(\mathrm{m})$, the depth of the mixed layer $z_{\mathrm{m}}(\mathrm{m})$ and the Sverdrup critical depth $Z_{\mathrm{cr}}(\mathrm{m})$ in the turbid plume, the intermediate plume and oceanic waters during BIOMET 2 and BIOMET 3. S: salinity. Values in italics are sample numbers

\begin{tabular}{|c|c|c|c|c|c|c|c|c|}
\hline & \multicolumn{4}{|c|}{ BIOMET 2} & \multicolumn{4}{|c|}{ BIOMET 3} \\
\hline & $K$ & $z_{\mathrm{e}}$ & $z_{\mathrm{m}}$ & $Z_{\mathrm{cr}}$ & $K$ & $z_{\mathrm{e}}$ & $z_{\mathrm{m}}$ & $Z_{\mathrm{cr}}$ \\
\hline $\begin{array}{l}\text { Turbid plume } \\
\qquad \mathrm{S}<33\end{array}$ & $\begin{array}{c}0.95 \pm 0.02 \\
2\end{array}$ & $\begin{array}{c}5 \pm 0.1 \\
2\end{array}$ & $\begin{array}{c}15 \pm 6 \\
2\end{array}$ & $\begin{array}{c}4 \pm 1 \\
13\end{array}$ & - & - & - & - \\
\hline Intermediate plume & $0.60 \pm 0.05$ & $7 \pm 1$ & $16 \pm 4$ & $7 \pm 2$ & $0.19 \pm 0.03$ & $24 \pm 5$ & $9 \pm 4$ & $35 \pm 10$ \\
\hline S: $33-35$ & 16 & 16 & 16 & 13 & 17 & 17 & 17 & 13 \\
\hline Oceanic waters & $0.3 \pm 0.02$ & $16 \pm 1$ & $>50$ & $13 \pm 4$ & $0.14 \pm 0.05$ & $35 \pm 10$ & $>60$ & $47 \pm 14$ \\
\hline $\mathrm{S}>35.5$ & 2 & 2 & 2 & 13 & 4 & 4 & 4 & 13 \\
\hline
\end{tabular}

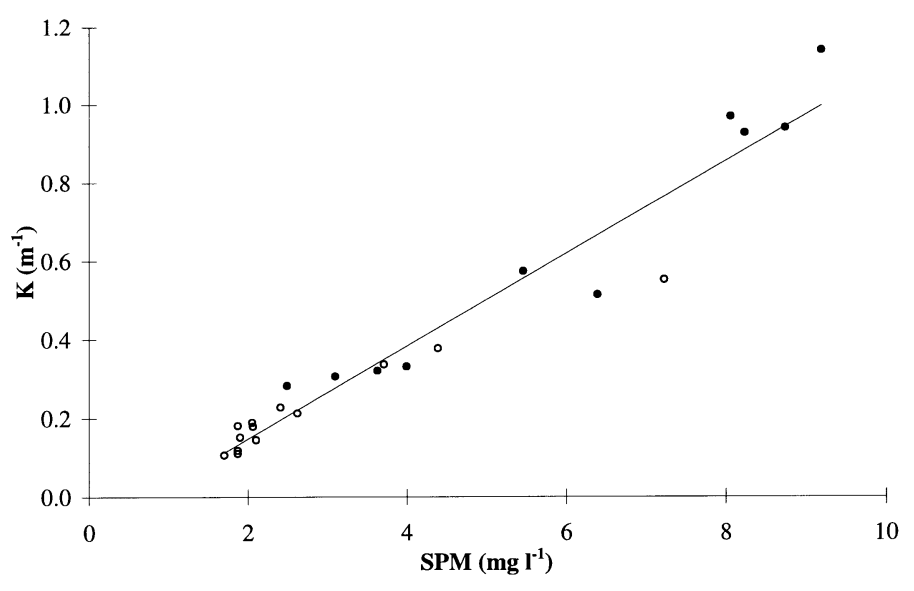

Fig. 4. Linear regression of the vertical attenuation coefficient $K$ for PAR against suspended particulate organic matter (SPM) concentration for BIOMET $2(\bullet)$ and BIOMET $3(\circ) . \mathrm{n}=23$,

$$
\mathrm{r}=0.971
$$

increased in the aphotic oceanic layer. However, nitrate and silicate reached relatively high concentrations in surface waters and low concentrations in bottom ones. In oceanic waters, phosphate was less deficient, but nitrate and silicate concentrations were sometimes below the detection limit.

\section{Chlorophyll $a$ and dominant phytoplankton species}

Low chl a values were measured in plume and oceanic waters during BIOMET 2, with homogeneous vertical distribution (Fig. 5g, Table 2). Integrated chl a concentrations were higher in oceanic $\left(16 \pm 4 \mathrm{mg} \mathrm{m}^{-2}\right.$, $\mathrm{n}=9)$ than in plume waters $\left(9 \pm 4 \mathrm{mg} \mathrm{m}^{-2}, \mathrm{n}=14\right)$. Between the cruises chl a increased dramatically both within plume and oceanic waters (Fig. 5h, Table 2), with a parallel increase of its contribution to the sum chl $a+$ phaeophytin a (from $49 \% \pm 14, \mathrm{n}=93$ during BIOMET 2, to $69 \% \pm 10, \mathrm{n}=143$ during BIOMET 3). Vertical distributions of chl a often showed an increase below the mixed layer (Table 2). Integrated values ranged from 10 to $105 \mathrm{mg} \mathrm{m}^{-2}$ with highest values in plume waters. Stratified waters under Loire influence had also high chl a concentrations.

An increase of surface chl a concentrations was also observed by SeaWiFS estimations recorded on 14 February 1998 along a NNW-SSE transect, southwest of the Gironde mouth, which was not observed before (Fig. 7). From the results of the 3D hydrodynamical model run for the same day, the corresponding zone was at the boundary between plume and oceanic waters (within salinity range 35 to 35.5 ). However, a chl a increase could have occurred in plume waters too, but such a development cannot be detected with SeaWiFS data because of the interference of turbidity in the determination of chl a when suspended matter concentrations are $>1 \mathrm{mg} \mathrm{l}^{-1}$ (Froidefond et al. in press).

More than $80 \%$ of the chl a was contained in microorganisms smaller than $20 \mu \mathrm{m}$ in early winter with a high percentage ( $54 \%$ ) in the size class 3 to $20 \mu \mathrm{m}$. The situation was reversed at BIOMET 3 when the contribution of phytoplankton $>20 \mu \mathrm{m}$ ranged from 50 to $80 \%$ of total chl a.

Counting and determination of phytoplankton species in the $>20 \mu \mathrm{m}$ size fraction of surface waters showed the dominance of diatoms in late winter. Coscinodiscus sp. was the dominant taxon with some Nitzschia sp., Thalassionema sp., Thalassiosira sp., Rhizosolenia sp., and Ditylum sp.

\section{Particulate organic matter}

No coherent vertical distribution pattern of the different elements $(C, N, P)$ of the particulate organic matter (POM) was evidenced during the 2 cruises. For that reason, POC, PON and POP were averaged for the whole water column (Table 3). The spatial distribution of POM clearly showed a negative gradient from the nearshore turbid plume waters to the offshore oceanic waters. Between cruises, POC and PON mean concentrations did not change, whereas POP concentrations increased by a factor of 1.8, 1.6 and 1.4 respectively in turbid, intermediate and oceanic waters. This increase 

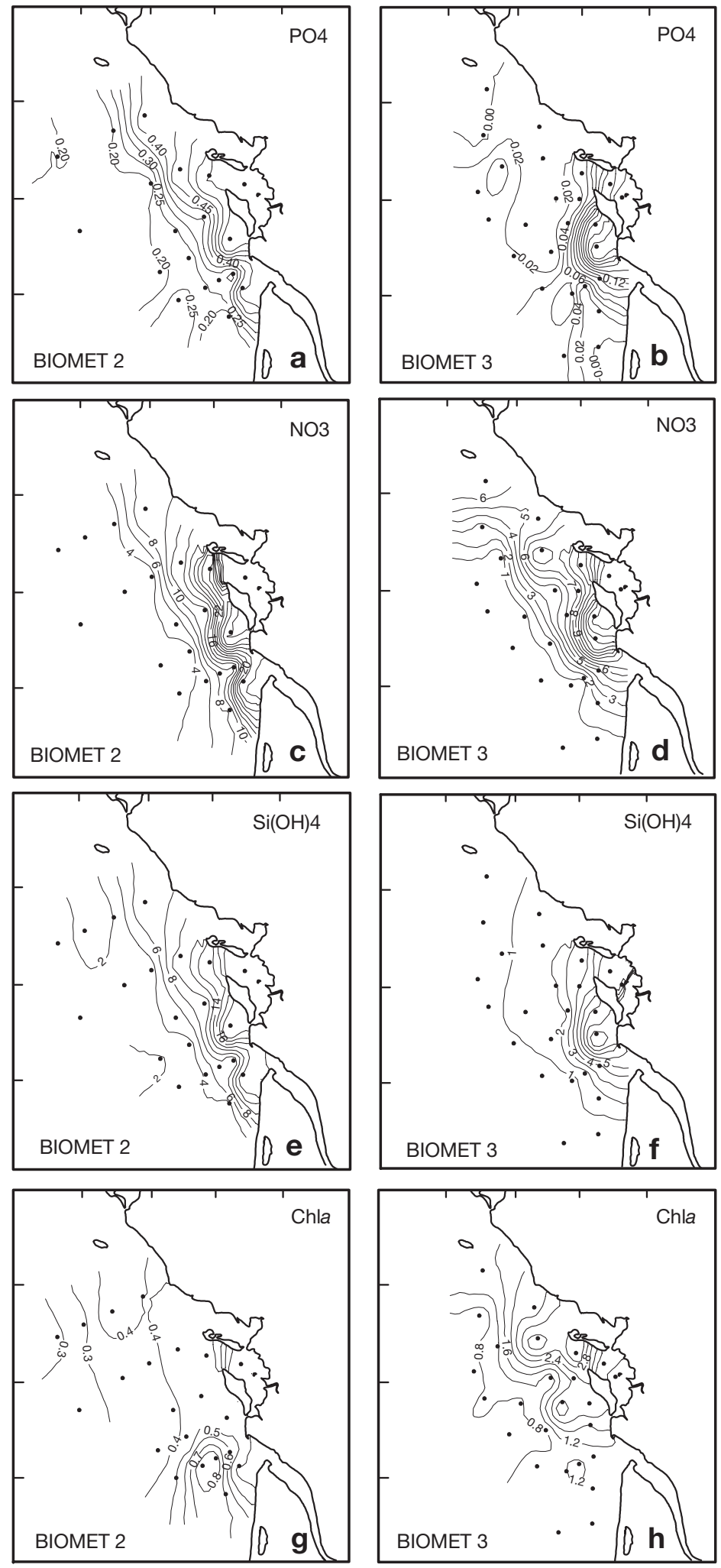

Fig. 5. Spatial distributions of nutrients $(\mu \mathrm{M})$ phosphate, nitrate, silicate and of chl a $\left(\mu \mathrm{g} \mathrm{l}^{-1}\right)$ as average concentrations in the mixed surface layer in the Bay of Biscay continental shelf during BIOMET 2 and BIOMET 3. Dots correspond to sampled stations co-occurred with the increase of phytoplankton biomass (chl a increased by a factor of 3.8, 3.0 and 2.5 for the respective waters during the same time, Table 2).

\section{DISCUSSION}

\section{Evidence of winter phytoplankton blooms}

Nutrient concentrations were conservative in early winter in the Gironde plume. This is consistent with the results of the 'Réseau National d'Observation' (French national net monitoring of the marine environment quality) concerning dilution scheme of nitrate and phosphate for the Gironde waters (within salinity range 5 to 35) during winters 1974 to 1984, 1988 to 1989 (RNO 1989-1990) and 1997 (Michel et al. 2000). On the contrary, biological consumption is obvious in late winter as shown by non-conservative nutrient concentrations in the mixed layer, within the salinity range 33 to 35 and by particularly small, often undetectable, phosphate concentrations. Below a salinity of 33, nutrients are conservative with lower values compared with those at BIOMET 2 because of seasonal differences in the Gironde runoff and nutrient concentrations at the source. In oceanic waters $(\mathrm{S}>35.5)$, phosphate concentrations also decreased, but were above the dilution straight line of Gironde waters probably because they originated from the mixing of 2 different water masses of highsalinity. In these oceanic waters, nitrate and silicate are particularly depleted (Table 2).

At the same time, chl a concentrations increased dramatically between early and late winter in the Gironde plume and oceanic waters (Fig. $5 \mathrm{~g}, \mathrm{~h}$ ) which is also confirmed by a SeaWiFS image recorded on 14 February 1998 (Fig. 7). Phytoplankton biomass was dominated by microorganisms larger than $20 \mu \mathrm{m}$ in late winter. Primary production data exhibit a similar pattern, with an increase of at least 1 order of magnitude in late winter and a main contribution of microorganisms larger than $20 \mu \mathrm{m}$ to the total production (not shown). Phytoplankton species were essentially composed of siliceous diatoms, typical of spring phytoplankton blooms. Chl a vertical distribution in late winter often showed a gradual increase under the mixed layer; this deep chl a would not already be degraded since the percentage of phaeopigments was as small as 

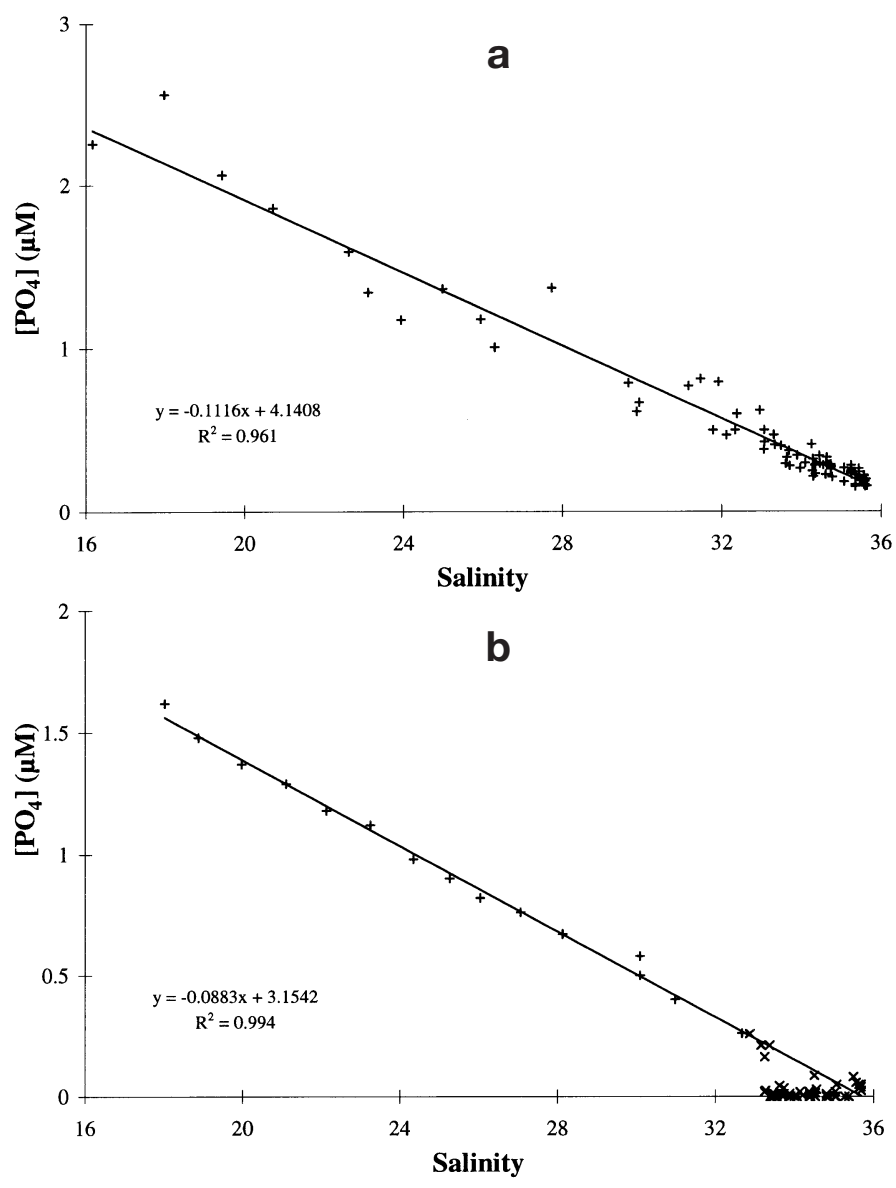

Fig. 6. Relation between phosphate and salinity in the mixed layer during (a) BIOMET 2 and (b) BIOMET 3. (a) Straight line is the linear regression of data from the Gironde plume and estuary (salinity range 16 to 35 ); (b) includes data from the salinity range 16 to 33 that in the mixed layer $(31 \% \pm 5, \mathrm{n}=13)$. This distribution could be the result of a strong and recent sedimentation from the mixed layer of phytoplankton cells having developed prior to BIOMET 3. Therefore, field data highlight the occurrence of a late winter phytoplankton bloom, responsible for the early exhaustion of phosphate in the Bay of Biscay continental shelf, which has the same characteristics as spring phytoplankton blooms of large diatoms.

The fact that spatial variations (decreasing values from the turbid plume to oceanic waters) of POC and PON were detectable on each cruise emphasizes the great importance of the non-phytoplanktonic organic matter supplied by the Gironde outflows in the POM of these waters (Table 3), which is also confirmed by the high C:N values (between 9 and 12), compared to the classical Redfield ratio (6.6). Calculations based on a C:chl a w:w ratio of 50:1 (Banse 1977) and Redfield C:N at:at ratio show that phytoplankton $\mathrm{C}$ and $\mathrm{N}$ increased by a factor of nearly 3.8, 3.0 and 2.5 between the 2 cruises respectively in turbid, intermediate and oceanic waters. At the same time, POC and PON did not significantly change (Table 3 ), which could be attributed to a parallel decrease of SPM (Fig. 4). As a result, phytoplankton $\mathrm{C}$ and $\mathrm{N}$ contribution increased between the 2 cruises since they represented for the whole Gironde plume an average of 10 and $16 \%$ of the respective POC and PON in early winter and 30 and $54 \%$ in late winter. In contrast to POC and PON, the POP values showed an increase between cruises by a factor of $1.8,1.6$ and 1.4 respectively in turbid, intermediate and oceanic waters, implying smaller C:P and particularly $\mathrm{N}:$ P ratios of particles (Table 3). As previously observed (Berland et al. 1988, Pujo-Pay 1995), in natural condi-

Table 2. Mean concentrations of phosphate, nitrate, silicate and chl $\mathrm{a}$ in the 0 to $20 \mathrm{~m}$ layer and deeper than $20 \mathrm{~m}$ layer during BIOMET 2 and 3 in the turbid plume (T), the intermediate plume (I) and oceanic waters (O). Values in parentheses are the standard deviations and values in italics are sample numbers. * For these stratified waters the mixed and bottom layers are considered

\begin{tabular}{|c|c|c|c|c|c|c|c|c|c|c|c|c|}
\hline \multirow[t]{2}{*}{ Layer (m) } & \multicolumn{3}{|c|}{$\mathrm{PO}_{4}(\mu \mathrm{M})$} & \multicolumn{3}{|c|}{$\mathrm{NO}_{3}(\mu \mathrm{M})$} & \multicolumn{3}{|c|}{$\mathrm{Si}(\mathrm{OH})_{4}(\mu \mathrm{M})$} & \multicolumn{3}{|c|}{ Chl a $\left(\mu g l^{-1}\right)$} \\
\hline & $\mathrm{T}$ & I & $\mathrm{O}$ & $\mathrm{T}$ & I & $\mathrm{O}$ & $\mathrm{T}$ & I & $\mathrm{O}$ & $\mathrm{T}$ & I & $\mathrm{O}$ \\
\hline \multicolumn{13}{|l|}{ BIOMET 2} \\
\hline 0 to 20 & $\begin{array}{c}0.65 \\
(0.12)\end{array}$ & $\begin{array}{c}0.27 \\
(0.09)\end{array}$ & $\begin{array}{c}0.19 \\
(0.03)\end{array}$ & $\begin{array}{l}22.9 \\
(5.8)\end{array}$ & $\begin{array}{c}6.6 \\
(3.2)\end{array}$ & $\begin{array}{c}2.7 \\
(0.3)\end{array}$ & $\begin{array}{l}15.9 \\
(4.2)\end{array}$ & $\begin{array}{c}5.5 \\
(2.3)\end{array}$ & $\begin{array}{c}2.2 \\
(0.5)\end{array}$ & $\begin{array}{c}0.51 \\
(0.15)\end{array}$ & $\begin{array}{c}0.53 \\
(0.19)\end{array}$ & $\begin{array}{c}0.32 \\
(0.07)\end{array}$ \\
\hline & 9 & 14 & 8 & 11 & 16 & 15 & 11 & 16 & 15 & 11 & 16 & 16 \\
\hline$>20$ & & $\begin{array}{c}0.23 \\
(0.03)\end{array}$ & $\begin{array}{c}0.20 \\
(0.05)\end{array}$ & & $\begin{array}{l}5.1 \\
(2.9)\end{array}$ & $\begin{array}{c}2.6 \\
(0.3)\end{array}$ & & $\begin{array}{c}4.7 \\
(2.3)\end{array}$ & $\begin{array}{c}2.2 \\
(0.5)\end{array}$ & & $\begin{array}{c}0.44 \\
(0.10)\end{array}$ & $\begin{array}{c}0.33 \\
(0.07)\end{array}$ \\
\hline & & 6 & 3 & & 7 & 14 & & 7 & 14 & & 7 & 14 \\
\hline \multicolumn{13}{|l|}{ BIOMET 3} \\
\hline 0 to 20 & $\begin{array}{c}0.20 \\
(0.06)\end{array}$ & $\begin{array}{c}0.010^{*} \\
(0.015)\end{array}$ & $\begin{array}{c}0.043 \\
(0.018)\end{array}$ & $\begin{array}{l}11.7 \\
(3.4)\end{array}$ & $\begin{array}{c}3.8^{*} \\
(2.9)\end{array}$ & $\begin{array}{c}0.3 \\
(0.2)\end{array}$ & $\begin{array}{c}7.5 \\
(2.3)\end{array}$ & $\begin{array}{c}1.7^{*} \\
(1.1)\end{array}$ & $\begin{array}{c}0.5 \\
(0.2)\end{array}$ & $\begin{array}{c}1.96 \\
(0.65)\end{array}$ & $\begin{array}{c}1.55^{*} \\
(0.96)\end{array}$ & $\begin{array}{c}0.82 \\
(0.21)\end{array}$ \\
\hline & 5 & 15 & 11 & 5 & 15 & 11 & 5 & 15 & 11 & 5 & 15 & 11 \\
\hline$>20$ & & $\begin{array}{c}0.057^{*} \\
(0.033)\end{array}$ & $\begin{array}{c}0.053 \\
(0.027)\end{array}$ & & $\begin{array}{c}1.4^{*} \\
(1.4)\end{array}$ & $\begin{array}{c}0.2 \\
(0.2)\end{array}$ & & $\begin{array}{c}1.5^{*} \\
(0.9)\end{array}$ & $\begin{array}{c}0.6 \\
(0.1)\end{array}$ & & $\begin{array}{c}2.14^{*} \\
(1.30)\end{array}$ & $\begin{array}{c}0.91 \\
(0.26)\end{array}$ \\
\hline & & 17 & 10 & & 17 & 9 & & 17 & 9 & & 13 & 9 \\
\hline
\end{tabular}




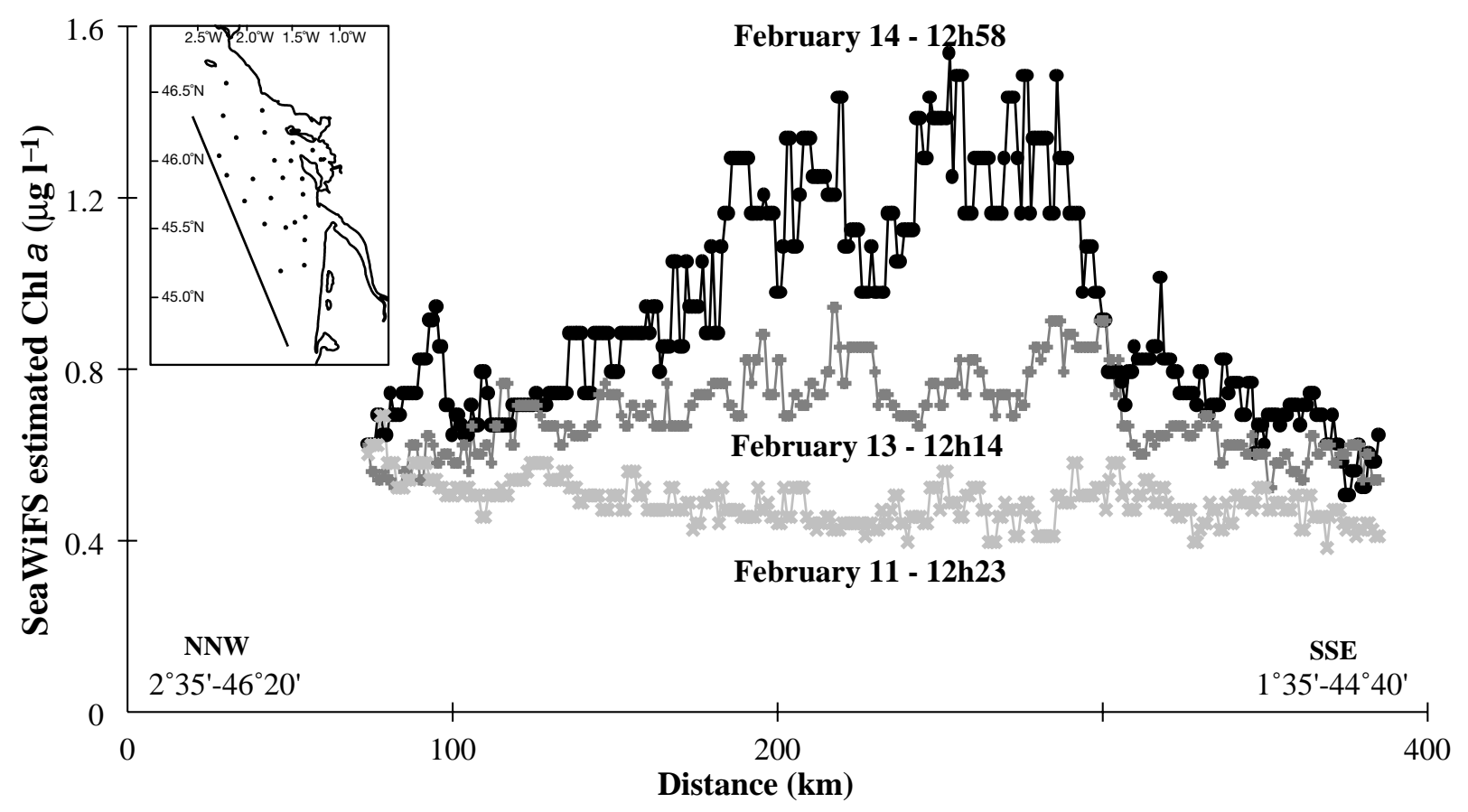

Fig. 7. SeaWiFS estimated chl a concentration along a NNW-SSE transect in the Bay of Biscay recorded on 11, 13, and 14 February 1998. Sampling grid at BIOMET 3 is represented on the transect location map

tions, the POP, more labile than POC and PON, is a better tracer of the living or recently synthetized organic matter. However, the increase of POP is smaller than that of phytoplankton $\mathrm{P}$ expected from the chl $a$ increase (deduced from a C:chl $a \mathrm{w}: \mathrm{w}$ ratio of 50:1 and Redfield C:P at:at ratio of 106). It could be interpreted as a P limitation at the end of the bloom.

\section{Causes of winter phytoplankton blooms}

The seasonal cycle of production and accumulation of phytoplankton biomass in the ocean is the result of an interplay of several factors, of which the most important are temperature, nutrient availability, grazing, and light availability as a function of incident light, stratification and vertical attenuation coefficient (Thórdardóttir 1986).

\section{Non-determining factors}

Temperature is known to have a positive effect on the growth rate of phytoplankton (Eppley 1972). In our study, despite a slightly higher seawater temperature in early than in late winter (difference of 0.5 to $1^{\circ} \mathrm{C}$ ), phytoplankton blooms still did not occur. Recent experiments with Gironde plume waters (cruises in the end of February 1999, data not shown) have displayed a stimulated phytoplankton growth, though temperature was as low as $10^{\circ} \mathrm{C}$, confirming that seawater temperature variations in winter would not affect the onset of phytoplankton blooms.

Because phosphate, nitrate and silicate concentrations in the intermediate and turbid plume waters were significantly higher than their respective classical half saturation constant $K_{\mathrm{s}}$ for uptake $(<0.1,0.5$ and $2 \mu \mathrm{M}$; Thingstad et al. 1993, Del Amo \& Brzezinski 1999, Kudela \& Cochlan 2000) at BIOMET 2 (Table 2, Fig. 5), nutrients were not limiting for phytoplankton growth in early winter in these waters. Since phytoplankton blooms were not initiated during these nutrient-replete conditions, nutrient availability should not be a triggering factor. On the contrary, silicate concentrations were close to their $K_{\mathrm{s}}$ in oceanic waters in early winter. However, they were sufficient to support an increase of 0.5 to $0.6 \mu \mathrm{g} \mathrm{chl} \mathrm{a}^{-1}$ (according to the yield of $1.1 \mu \mathrm{g}$ chl a from $1 \mu \mathrm{M} \mathrm{N}$ and equilibrated N:Si at:at ratio of 1 for diatom growth; Gowen et al. 1992), as it was observed between early and late winter (Table 2), and they should not be the determining factor for the initiation of blooms. Obviously, the winter phytoplankton bloom should be limited by phosphate and silicate in the intermediate plume $(0.010$ and $1.7 \mu \mathrm{M})$, while nitrate and silicate should be the limiting nutrients in oceanic waters $(0.3$ and $0.5 \mu \mathrm{M})$.

Grazing is known to limit the magnitude of spring blooms in coastal waters (Thórdardóttir 1986, Yin et al. 
Table 3. Mean concentration and composition of the particulate organic matter in terms of carbon (POC), nitrogen (PON) and phosphorus (POP) in the water column of the turbid plume, the intermediate plume and oceanic waters during BIOMET 2 and BIOMET 3. Values in parentheses are the standard deviations and values in italics are sample numbers

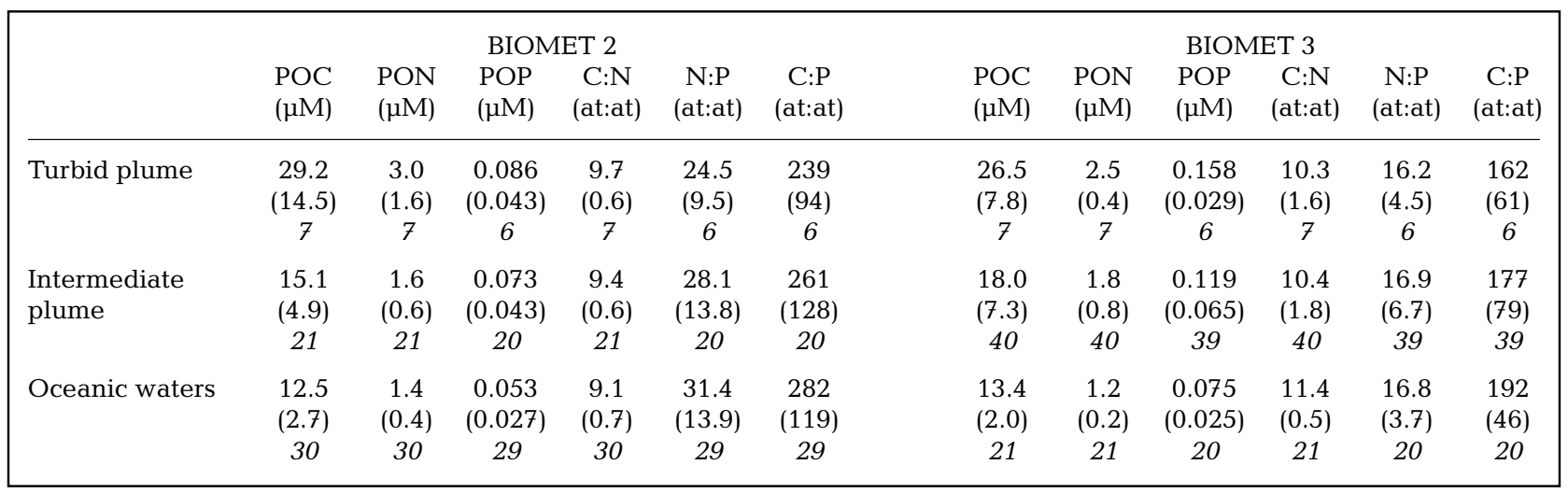

1996), and relaxation of grazing pressure was responsible for the onset of winter-spring phytoplankton blooms in coastal waters of Narragansett Bay (Pratt 1965, Martin 1970). In the Gironde plume, mesozooplankton abundance increased between early and late winter parallel to an increase of phytoplankton biomass, and grazing pressure on chl a remained the same (Vincent \& Hartmann in press). Thus temperature, nutrient availability, and grazing relaxation do not seem to be the factors responsible for the initiation of the 1998 winter phytoplankton bloom.

\section{Determining factors acting on light availability}

The Sverdrup (1953) critical depth model (SCDM) implies that available light, as the depth-averaged irradiance $\left(E_{\mathrm{m}}\right)$ received by phytoplankton within the water column, is the most important factor for the initiation of phytoplankton blooms. It establishes that, for a fixed incident irradiance, there is a critical depth $\left(Z_{\mathrm{cr}}\right)$ above which phytoplankton reach positive net photosynthesis (production exceeds losses) on a $24 \mathrm{~h}$ basis and can develop. In other words, the depth of the mixed layer $\left(z_{\mathrm{m}}\right)$ must be smaller than the critical depth for the outburst of phytoplankton. The Sverdrup model hypothesizes non-limiting nutrient conditions and homogeneous mixing of phytoplankton cells in the mixed layer. Sathyendranath \& Platt (1994) consider that the premises of this concept are so fundamental that they must be true. Smetacek \& Passow (1990) discuss some shortcomings of the model, especially with regard to the definition of the term of respiration. Also, some inconsistent observations of spring blooms in the absence of vertical stratification (Townsend et al. 1992, Eilertsen 1993) were recently underpinned by Huisman et al. (1999). The latter developed a turbulent diffusion model which distinguishes 2 different mechanisms for the outburst of phytoplankton blooms: the SCDM in well-mixed environments and a theory of a critical turbulence below which 'phytoplankton growth rates exceed the vertical mixing rates, and a bloom develops irrespective of the depth of the upper water layer'. Lucas et al. (1998) use numerical models to explore the possible application of the SCDM to estuarine waters. They point out that semidiurnal fluctuations of stratification generated by the tide cycle do not increase the likelihood of a phytoplankton bloom over that of a constantly unstratified water column. They provide evidence that SCDM must be refined for application in shallow tidally driven systems where processes missing from the model, that is the leakage of phytoplankton from the surface layer via sinking and turbulent mixing, are important. These situations occur where the influence of freshwater is relatively weak and tidal cycle is dominant, as in south San Francisco Bay. In the Gironde plume waters, tidal currents are weak (Pingree et al. 1982), and their influence is limited to the Gironde estuary mouth at depths shallower than $20 \mathrm{~m}$. The primary sources of turbulence are the wind and the density-driven flows (Lazure \& Jegou 1998). In such conditions, the haline stratification due to freshwater outflows is persistent for several months when established. Therefore the depth of the mixed layer is constant and well-defined at the phytoplankton bloom scale (several days). Calculation of depth-averaged irradiance received by phytoplankton in that layer is therefore justified. $E_{\mathrm{m}}$ is given by the relation:

$$
E_{\mathrm{m}}=\left(E_{0}-E_{0} \times \mathrm{e}^{-K z_{\mathrm{m}}}\right) / K z_{\mathrm{m}}
$$

$E_{\mathrm{m}}$ is calculated by taking $E_{0}$ as the total surface incident irradiance ( $\mathrm{W} \mathrm{m}^{-2}$; Riley 1957) or as incident PAR $\left(\mu\right.$ Einst $\left.\mathrm{m}^{-2} \mathrm{~s}^{-1}\right)$, and $K$ as the vertical attenuation coefficient for PAR $\left(\mathrm{m}^{-1}\right)$.

The importance of available light for phytoplankton growth in winter within the Gironde plume can be first 
evidenced by comparison of instantaneous mean PAR irradiance $\left(E_{\mathrm{m}}\right)$ received by phytoplankton in the daytime during BIOMET 2 and BIOMET 3 and the measured $E_{k}$ (the irradiance level above which light is not limiting; Sakshaug et al. 1997). The purpose of comparing $E_{\mathrm{m}}$ with $E_{k}$ consists in determining if light is limiting or not for phytoplankton growth, as was already suggested by Jellison \& Melack (1993). $E_{k}$ values in the Gironde intermediate plume in late winter averaged $350 \pm 88 \mu$ Einst $\mathrm{m}^{-2} \mathrm{~s}^{-1}$ (Table 4 ). In early winter, $E_{k}$ values were not measured but were approximated to those found in late winter since they are close to the range of values previously measured in the winter of 1996 from December to March on the waters of the Pertuis Breton (position in Fig. 1a, Herbland unpubl. data). $E_{\mathrm{m}}$ was always below $E_{k}$ during BIOMET 2 in the daytime, whereas it was above $E_{k}$ during $40 \%$ of the daylight in late winter (18\% of the whole day) in plume waters (Table 4). For comparison, we observed a similar proportion of the daylight for sunny days in the same area in mid June 1998 (cruise PEGASE), when incident irradiance is known not to be limiting, and for which $E_{k}$ was higher $\left(465 \pm 82 \mu\right.$ Einst $\left.\mathrm{m}^{-2} \mathrm{~s}^{-1}\right)$. The percentage of the whole day is higher in June because of longer daylight hours. Therefore, the comparison between $E_{\mathrm{m}}$ and $E_{k}$ leads to the conclusion that available light was limiting in early winter when phytoplankton blooms were not initiated and was not limiting during a large part of the day after the onset of blooms. It does not prove that available light was responsible for bloom initiation, but its status changed dramatically between cruises and the potential for light as the triggering factor is to be tested.

Nelson \& Smith's (1991) reformulation of the Sverdrup equation for $Z_{\text {cr }}$ with regard to better consistency with present-day optical and biological data was validated for the control of Southern Ocean productivity. It was applied to the Gironde plume with the following form:

$$
Z_{\text {cr }}=0.85 \times(1-r) \times E_{0} /\left(K \times I_{\mathrm{c}}\right)
$$

The factor 0.85 takes into account the approximate $15 \%$ loss of PAR due to the absorption of the band 650 to $700 \mathrm{~nm}$ in the upper few metres of the water column. $r$ is the part of reflected PAR. The measured values of $r$ (see Froidefond et al. in press for the methods) ranged from 0.04 in oceanic waters to 0.06 in the turbid plume at BIOMET 2 and from 0.01 to 0.015 in oceanic and intermediate plume waters respectively at BIOMET $3 . E_{0}$ is the time-integrated PAR for a $24 \mathrm{~h}$ period expressed in $\mu$ Einst $\mathrm{m}^{-2} \mathrm{~s}^{-1} . I_{\mathrm{c}}$ is the irradiance at the photocompensation depth. It was estimated to be approximately $35 \mu$ Einst $\mathrm{m}^{-2} \mathrm{~s}^{-1}$ by Perry \& Marra (unpubl.) in the Gulf of Maine taking into account most naturally occurring losses of phytoplankton biomass which must be considered in the respiration term of SCDM (grazing, sinking). Results show that $Z_{\text {cr }}$ was largely shallower than $Z_{\mathrm{m}}$
Table 4. Mean values of measured light saturation parameter $E_{k}$ and mean time in the daytime (percentage of the daylight and of $24 \mathrm{~h}$ ) during which instantaneous depth averaged visible irradiance $E_{\mathrm{m}}$ exceeded $E_{\mathrm{k}}$. Comparisons are shown for the cruises BIOMET 2, BIOMET 3 and PEGASE (7-20 June 1998) in intermediate plume waters. Values in parentheses are ranges of values. $n=10$

\begin{tabular}{|c|c|c|c|}
\hline & BIOMET 2 & BIOMET 3 & PEGASE \\
\hline $\begin{array}{l}E_{k} \\
\left(\mu \text { Einst } \mathrm{m}^{-2} \mathrm{~s}^{-1}\right)\end{array}$ & 350 & $\begin{array}{l}350 \pm 88 \\
(226-480)\end{array}$ & $\begin{array}{c}465 \pm 82 \\
(390-593)\end{array}$ \\
\hline $\begin{array}{l}\text { Mean time with } E_{\mathrm{m}}>E_{k} \\
\text { (\% of daylight) }\end{array}$ & ik & $\begin{array}{l}40 \pm 15 \\
(17-63)\end{array}$ & $\begin{array}{l}48 \pm 14 \\
(28-60)\end{array}$ \\
\hline $\begin{array}{l}\text { Mean time with } E_{\mathrm{m}}>E_{\mathrm{k}} \\
(\% \text { of } 24 \mathrm{~h})\end{array}$ & 0 & $\begin{array}{l}18 \pm 7 \\
(8-28)\end{array}$ & $\begin{array}{c}30 \pm 9 \\
(19-40)\end{array}$ \\
\hline
\end{tabular}

in early winter, whereas $Z_{\text {cr }}(35 \mathrm{~m})$ was greatly deeper than $Z_{\mathrm{m}}(9 \mathrm{~m})$ in the intermediate plume in late winter (Table 1). For oceanic waters, $z_{\mathrm{m}}$ is estimated as the depth of the bottom ( 60 to $70 \mathrm{~m}$ ) and is within the range of values for $Z_{\text {cr }}$ in late winter. Therefore, according to the Sverdrup model, available light received by phytoplankton was not sufficient for the outburst of bloom in the Gironde plume and oceanic waters in early winter, although it was sufficient in late winter. It confirms that available light is the triggering factor of winter phytoplankton blooms in the Gironde plume and adjacent oceanic waters.

Comparing bloom occurrence periods in numerous estuaries on the east coast of the United States and the corresponding depth-averaged irradiance, Riley (1957) suggests an empirical critical irradiance of $0.03 \mathrm{~g}$ cal $\mathrm{cm}^{-2} \min ^{-1}\left(=20.9 \mathrm{~W} \mathrm{~m}^{-2}\right)$ required for blooming in temperate coastal waters. This value is a monthly average of $24 \mathrm{~h}$ integrations of the total amount of light received in the mixed layer. Application of this critical value enabled a prediction of the onset of phytoplankton blooms in Narragansett Bay (Hitchcock \& Smayda 1977), and it was applied with success on the Armorican shelf of the northwest Bay of Biscay (Morin et al. 1991). In our case, weekly mean irradiance calculated during BIOMET 2 in the intermediate plume with actual $K$ and $z_{\mathrm{m}}$ values $\left(0.60 \mathrm{~m}^{-1}\right.$ and $16 \mathrm{~m}$ respectively, Table 1) is below Riley's critical value (Table 5). Those calculated during BIOMET 3 with $K$ and $z_{\mathrm{m}}$ values of $0.19 \mathrm{~m}^{-1}$ and $9 \mathrm{~m}$ were greatly above. In oceanic waters, mean irradiance was strongly below Riley's critical value during BIOMET 2 and came close to Riley's limit during BIOMET 3. The reaching of Riley's critical mean irradiance during BIOMET 3 and not during BIOMET 2, together with observed phytoplankton blooms during BIOMET 3, point out that Riley's critical mean irradiance $\left(20.9 \mathrm{~W} \mathrm{~m}^{-2}\right)$ could be applied within the Gironde plume and adjacent oceanic waters to predict the onset of phytoplankton blooms. 
Table 5. Weekly depth-averaged total irradiance $E_{\mathrm{m}}\left(\mathrm{W} \mathrm{m}^{-2}\right)$ in the Gironde intermediate plume and oceanic waters during periods relevant to BIOMET 2 and 3

\begin{tabular}{|lcc|}
\hline Date & Intermediate plume & Oceanic waters \\
\hline 1-8 Jan & 6.8 & 4.5 \\
9-16 Jan & 8.5 & 5.6 \\
17-24 Jan & 9.7 & 6.3 \\
21-28 Feb & 56.0 & 14.4 \\
1-8 Mar & 73.2 & 18.8 \\
9-16 Mar & 73.4 & 18.9 \\
\hline
\end{tabular}

The calculation of the minimum incident irradiance required for onset of phytoplankton bloom (with Riley's $E_{\mathrm{m}}$ critical value and in terms of $K$ and $z_{\mathrm{m}}$, Fig. 8) shows that this minimum required is significantly lower in intermediate (I) and oceanic waters $(\mathrm{O})$ during BIOMET 3 (respectively $\approx 50$ and $175 \mathrm{~W} \mathrm{~m}^{-2}$ ) than during BIOMET 2 (respectively 200 and $325 \mathrm{~W} \mathrm{~m}^{-2}$ ) because of change in $K$ and $z_{\mathrm{m}}$ conditions. In the same time, the incident irradiance slightly increased from an average of $85 \mathrm{~W} \mathrm{~m}^{-2}$ in January to $128 \mathrm{~W} \mathrm{~m}^{-2}$ in February. This indicates that changes in water column stratification and vertical attenuation coefficient (correlated with turbidity) prevail upon the incident irradiance in the initiation process of winter phytoplankton blooms. In oceanic waters with a bottom depth of 60 to $70 \mathrm{~m}$, the decrease of $K$ was essential for the increase of phytoplankton biomass.

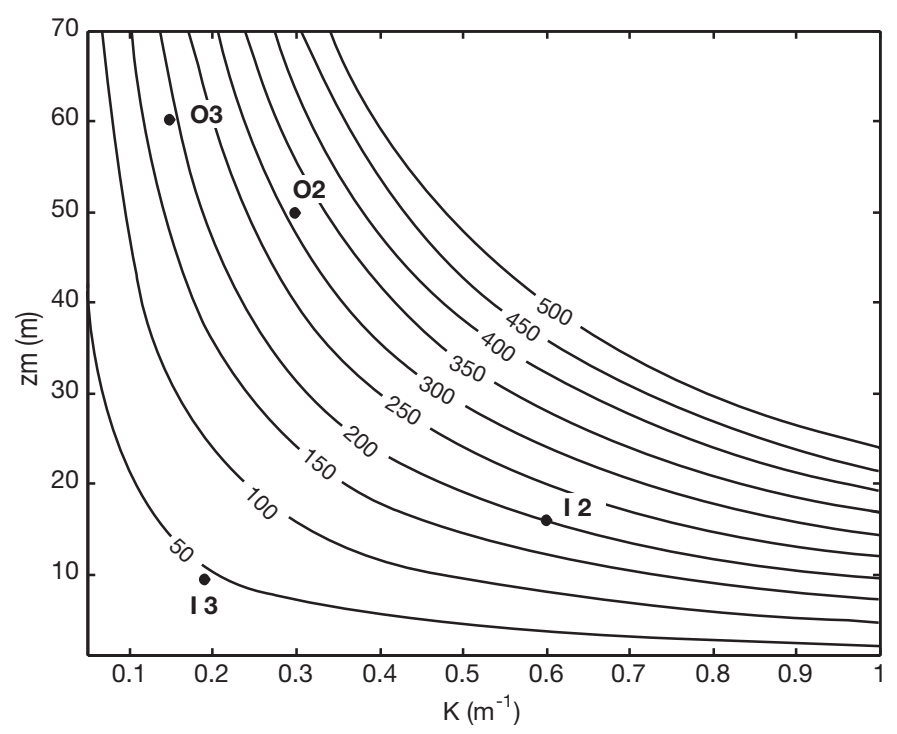

Fig. 8. Minimum incident irradiance $\left(E_{0} ; \mathrm{W} \mathrm{m}^{-2}\right)$ required for phytoplankton bloom initiation as a function of the depth of the mixed layer $Z_{\mathrm{m}}$, vertical attenuation coefficient $K$ and using Riley's critical mean irradiance $\left(E_{\mathrm{m}}\right)$ of $20.9 \mathrm{~W} \mathrm{~m}^{-2}$. $K$ and $Z_{\mathrm{m}}$ for intermediate plume and oceanic waters are plotted during BIOMET 2 (respectively I2, O2) and BIOMET 3 (respectively I3, O3)
The role of halostratification for the outburst of phytoplankton has been previously described in coastal waters (Thórdardóttir 1986, Morin et al. 1991, Yin et al. 1996). It was often studied in tidal estuaries (Fortier \& Legendre 1979, Cloern 1984, 1991, Pennock 1985, Demers et al. 1986, Pennock \& Sharp 1994, Ragueneau et al. 1996). In such systems stratification dynamic is complex with variability associated with the semidiurnal and weekly fluctuations in tidal energy (Simpson et al. 1990, Cloern 1991, Koseff et al. 1993, Lucas et al. 1998). In the eastern part of the Bay of Biscay, tidal currents are weak and the evolution of river plumes depends on the river runoff and winds (Lazure \& Jegou 1998). In early winter 1998, northward-alongshore extension of the Gironde plume is linked to high Gironde runoff $\left(1500 \mathrm{~m}^{3} \mathrm{~s}^{-1}\right)$ and southwest winds. However, in late winter, offshore extension is ascribed to weak river runoff $\left(650 \mathrm{~m}^{3} \mathrm{~s}^{-1}\right)$ and northeast winds. The transition between these 2 physical regimes corresponds to the transition from high vertical mixing-high vertical attenuation coefficient to halostratification-low vertical attenuation coefficient. Variations from year to year in runoff, direction and velocity of winds should have a determining effect on the timing of phytoplankton blooms, as was previously suggested in other coastal waters (Winter et al. 1975, Erga \& Heimdal 1984, Ingram et al. 1985, Thórdardóttir 1986, Yin et al. 1996). As $E_{0}$ is a meteorological measurement easily accessible and $z_{\mathrm{m}}$ and $K$ could be approximated by, respectively, the $3 \mathrm{D}$ hydrodynamical model and the SeaWiFS data, which provide values of $K$ at $490 \mathrm{~nm}$, it becomes possible, using Riley's $E_{\mathrm{m}}$ critical value (Fig. 8), to determine the timing of blooms in the Bay of Biscay continental shelf.

\section{CONCLUSION}

The initial hypothesis of this study that phytoplankton blooms occur early in the year, and are responsible for the early exhaustion of phosphate in the mixed layer of the Gironde plume is verified for winter 1998. These winter blooms have the characteristics of classical spring blooms (i.e. large diatoms) for temperate waters. The environmental conditions required for the outburst of phytoplankton are an increase of light availability by the establishment of haline stratification and/or the weakness of the vertical attenuation coefficient. The consequences on the planktonic food web would be similar to those observed during spring 1995 in the same area (Herbland et al. 1998), which means the structuration of the planktonic food web towards the dominance of small phytoplankton cells $(<3 \mu \mathrm{m})$ and grazing mainly realized by microzooplankton (Sautour et al. 2000). 
Finally, we can suppose that similar processes are effective for the Loire, the other large river on the French Atlantic coast. Other studies are necessary to (1) validate this extrapolation, (2) define the variability in space, time and intensity of the winter phytoplankton blooms, and (3) understand the food web consequences, especially towards a perspective of small pelagic resources.

Acknowledgements. Special thanks to the referees whose modifications improved the paper. This research was supported by the French 'Programme National d'Océanographie Côtière'. We thank Françoise Mornet and Lucette Joassard for respective nutrients and particulate organic matter analysis; Cedric Bacher for the calculation of $E_{k}$ and mathematical applications, Marcel Guillaut for record of total irradiance data and Alain Fillon for his assistance in the use of geographic tools.

\section{LITERATURE CITED}

Banse K (1977) Determining the carbon-to-chlorophyll ratio of natural phytoplankton. Mar Biol 41:199-212

Berland BR, Benzhitski AG, Burlakova ZP, Georgieva LV, Izmestieva MA, Kholodov VI, Maestrini SY (1988) Conditions hydrologiques estivales en Méditerranée, répartition du phytoplancton et de la matière organique. In: Minas HJ, Nival P (eds) Océanographie pélagique méditerranéenne. Oceanol Acta N Sp9:163-177

Botas JA, Fernández E, Bode A, Anadon R (1990) A persistent upwelling off the Central Cantabrian Coast (Bay of Biscay). Estuar Coast Shelf Sci 30:185-199

Castaing P, Froidefond JM, Lazure P, Weber O, Prud'homme R, Jouanneau JM (1999) Relationship between hydrology and seasonal distribution of suspended sediments on the continental shelf of the Bay of Biscay. Deep-Sea Res II 46: 1979-2001

Cloern JE (1984) Temporal dynamics and ecological significance of salinity stratification in an estuary (South San Francisco Bay, USA). Oceanol Acta 7:137-141

Cloern JE (1991) Tidal stirring and phytoplankton bloom dynamics in an estuary. J Mar Res 49:203-221

Del Amo Y, Brzezinski MA (1999) The chemical form of dissolved Si taken up by marine diatoms. J Phycol 35: $1162-1170$

Demers S, Legendre L, Therriault JC (1986) Phytoplankton responses to vertical tidal mixing. In: Bowman MJ, Yentsch CM, Peterson WT (eds) Tidal mixing and plankton dynamics. Springer-Verlag, Berlin, p 1-40

Eilertsen HC (1993) Spring blooms and stratification. Nature 363:24

Eppley RW (1972) Temperature and phytoplankton growth in the sea. Fish Bull 70:1063-1085

Erga SR, Heimdal BR (1984) Ecological studies on the phytoplankton of Korsfjorden, western Norway. The dynamics of a spring bloom seen in relation to hydrographical conditions and light regime. J Plankton Res 6:67-90

Fernández E, Bode A (1991) Seasonal patterns of primary production in the Central Cantabrian Sea (Bay of Biscay). Sci Mar 55:629-636

Fortier L, Legendre L (1979) Le contrôle de la variabilité à court terme du phytoplancton estuarien: stabilité verticale et profondeur critique. J Fish Res Board Can 36:1325-1335

Froidefond JM, Lavender S, Laborde P, Herbland A, Lafon V (in press) SeaWiFS data interpretation in a coastal area in the Bay of Biscay. Int J Remote Sensing

Gowen RJ, Tett P, Jones KJ (1992) Predicting marine eutrophication: the yield of chlorophyll from nitrogen in Scottish coastal waters. Mar Ecol Prog Ser 85:153-161

Herbland A, Delmas D, Laborde P, Sautour B, Artigas F (1998) Phytoplankton spring bloom of the Gironde plume waters in the Bay of Biscay: early phosphorus limitation and foodweb consequences. Oceanol Acta 21:279-291

Hitchcock GL, Smayda TJ (1977) The importance of light in the initiation of the 1972-1973 winter-spring diatom bloom in Narragansett Bay. Limnol Oceanogr 22:126-131

Holm-Hansen O, Lorenzen CJ, Holmes RW, Strickland JDH (1965) Fluorometric determination of chlorophyll. J Cons Perm Int Explor Mer 30:3-15

Huisman J, Van Oostveen P, Weissing FJ (1999) Critical depth and critical turbulence: two different mechanisms for the development of phytoplankton blooms. Limnol Oceanogr 44:1781-1787

Ingram RG, Legendre L, Simard Y, Lepage S (1985) Phytoplankton response to freshwater runoff: the diversion of the Eastmain River, James Bay. Can J Fish Aquat Sci 42: 1216-1221

Jassby AD, Platt T (1976) Mathematical formulation of the relationship between photosynthesis and light for phytoplankton. Limnol Oceanogr 21:540-547

Jellison R, Melack JM (1993) Algal photosynthetic activity and its response to meromixis in hypersaline Mono Lake, California. Limnol Oceanogr 38:818-837

Jitts HR, Morel A, Saijo Y (1976) The relation of oceanic primary production to available photosynthetic irradiance. Aust J Mar Freshw Res 27:441-454

Koseff JR, Holen JK, Monismith SG, Cloern JE (1993) Coupled effects of vertical mixing and benthic grazing on phytoplankton populations in shallow, turbid estuaries. J Mar Res 51:843-868

Kudela RM, Cochlan WP (2000) Nitrogen and carbon uptake kinetics and the influence of irradiance for a red tide bloom off southern California. Aquat Microb Ecol 21:31-47

Lazure P, Jegou AM (1998) 3D modelling of seasonal evolution of Loire and Gironde plumes on Biscay Bay continental shelf. Oceanol Acta 21:165-177

Levasseur M, Therriault JC, Legendre L (1984) Hierarchical control of phytoplankton succession by physical factors. Mar Ecol Prog Ser 19:211-222

Lewis MR, Smith JC (1983) 'Photosynthetron': a small volume, short-incubation time method for measurement of photosynthesis as a function of incident irradiance. Mar Ecol Prog Ser 13:99-102

Longhurst A (1995) Seasonal cycles of pelagic production and consumption. Prog Oceanogr 36:77-167

Longhurst A (1998) Ecological geography of the sea. Academic Press, San Diego

Lucas LV, Cloern JE, Koseff JR, Monismith SG, Thompson JK (1998) Does the Sverdrup critical depth model explain bloom dynamics in estuaries? J Mar Res 56:375-415

Martin JH (1970) Phytoplankton-zooplankton relationships in Narragansett Bay. The seasonal importance of grazing. Limnol Oceanogr 15:413-418

Michel P, Boutier B, Chiffoleau JF (2000) Net fluxes of dissolved arsenic, cadmium, copper, zinc, nitrogen and phosphorus from the Gironde estuary (France): seasonal variations and trends. Estuar Coast Shelf Sci 51:451-462

Morel A, Smith RC (1974) Relation between total quanta and total energy for aquatic photosynthesis. Limnol Oceanogr 19:591-600

Morin P, Le Corre P, Marty Y, L'Helguen S (1991) Evolution 
printanière des éléments nutritifs et du phytoplancton sur le plateau continental armoricain (Europe du NordOuest). Oceanol Acta 14:263-279

Nelson DM, Smith WO Jr (1991) Sverdrup revisited: critical depths, maximum chlorophyll levels, and the control of Southern Ocean productivity by the irradiance-mixing regime. Limnol Oceanogr 36:1650-1661

Pennock JR (1985) Chlorophyll distributions in the Delaware estuary : regulation by light-limitation. Estuar Coast Shelf Sci 21:711-725

Pennock JR, Sharp JH (1994) Temporal alternation between light- and nutrient-limitation of phytoplankton production in a coastal plain estuary. Mar Ecol Prog Ser 111:275-288

Pingree RD, Mardell GT, Holligan PM, Griffiths DK, Smithers J (1982) Celtic sea and Armorican current structure and the vertical distribution of temperature and chlorophyll $a$. Cont Shelf Res 1:99-116

Pratt DM (1965) The winter-spring diatom flowering in Narragansett Bay. Limnol Oceanogr 10:173-184

Pujo-Pay M (1995) L'azote et le phosphore en milieu marin. Importance des formes organiques en milieu océanique du large. PhD thesis, University of Aix Marseille II

Pujo-Pay M, Raimbault P (1994) Improvement of the wet-oxidation procedure for simultaneous determination of particulate organic nitrogen and phosphorus collected on filters. Mar Ecol Prog Ser 105:203-207

Ragueneau O, Quéguiner B, Tréguer P (1996) Contrast in biological responses to tidally induced vertical mixing for two macrotidal ecosystems of Western Europe. Estuar Coast Shelf Sci 42:645-665

Riley GA (1957) Phytoplankton of the North Central Sargasso Sea. Limnol Oceanogr 2:252-270

RNO (Réseau National d'Observation de la qualité du milieu marin) (1989-1990) Surveillance du milieu marin. Travaux du RNO. Ministère de l'environnement and IFREMER (eds). INSTAPRINT, Tours, p 7-13

Sakshaug E, Bricaud A, Dandonneau Y, Falkowski PG, Kiefer DA, Legendre L, Morel A, Parslow J, Takahashi M (1997) Parameters of photosynthesis: definitions, theory and interpretation of results. J Plankton Res 19:1637-1670

Editorial responsibility: Yves Collos (Contributing Editor), Montpellier, France
Sathyendranath S, Platt T (1994) New production and mixedlayer physics. Proc Ind Acad Sci 103:177-188

Sautour B, Artigas LF, Delmas D, Herbland A, Laborde P (2000) Grazing impact of micro- and mesozooplankton during a spring situation in coastal waters off the Gironde estuary. J Plankton Res 22:531-552

Simpson JH, Brown J, Matthews J, Allen G (1990) Tidal straining, density currents, and stirring in the control of estuarine stratification. Estuaries 13:125-132

Smetacek V, Passow U (1990) Spring bloom initiation and Sverdrup critical-depth model. Limnol Oceanogr 35:228-234

Strickland JDH, Parsons TR (1972) A practical handbook of seawater analysis. Bull Fish Res Board Can 167:45-89

Sverdrup HU (1953) On conditions for the vernal blooming of phytoplankton. J Cons Perm Int Explor Mer 18:287-295

Talling JF (1957) Photosynthetic characteristics of some freshwater plankton diatoms in relation to underwater radiation. New Phytol 56:29-50

Thingstad TF, Skjoldal EF, Bohme RA (1993) Phosphorus cycling and algal-bacterial competition in Sandsfjord, western Norway. Mar Ecol Prog Ser 99:239-259

Thórdardóttir T (1986) Timing and duration of spring blooming south and southwest of Iceland. In: Skrelet $\mathrm{S}$ (ed) The role of freshwater outflow in coastal marine ecosystems. Springer-Verlag, Berlin, p 345-360

Townsend DW, Keller MD, Sieracki ME, Ackleson SG (1992) Spring phytoplankton blooms in the absence of vertical water column stratification. Nature 360:59-62

Varela M (1996) Phytoplankton ecology in the Bay of Biscay. Sci Mar 60:45-53

Vincent D, Hartmann HJ (in press) Contribution of ciliated microprotozoans and dinoflagellates to the diet of three Calanoid copepods in the Bay of Biscay. Hydrobiologia

Winter KF, Banse K, Anderson GC (1975) The dynamics of phytoplankton blooms in Puget Sound, a fjord in the Northwestern United States. Mar Biol 29:139-176

Yin K, Harrison PJ, Goldblatt RH, Beamish RJ (1996) Spring bloom in the central Strait of Georgia: interactions of river discharge, winds and grazing. Mar Ecol Prog Ser 138: 255-263

Submitted: December 15, 1999; Accepted: August 25, 2000 Proofs received from author(s): February 26, 2001 